\title{
DETERIORATIONS OF PULMONARY FUNCTION, ELEVATED CARBON MONOXIDE LEVELS AND INCREASED OXIDATIVE STRESS AMONGST WATER-PIPE SMOKERS
}

\section{FUNDA KARADUMAN YALCIN ${ }^{1}$, MUKREMIN ER ${ }^{2}$, H. CANAN HASANOGLU ${ }^{3}$, HATICE KILIC ${ }^{2}$, AYSEGUL SENTURK ${ }^{2}$, AYSEGUL KARALEZLI ${ }^{3}$, MERVE ERGIN $^{4}$, and OZCAN EREL ${ }^{5}$}

175 th Year State Hospital, Sinop, Boyabat, Turkey

Department of Pulmonary Diseases

${ }^{2}$ Atatürk Research and Training Hospital, Bilkent, Ankara, Turkey

Department of Pulmonary Diseases

${ }^{3}$ Yildirim Beyazit University Medical School, Ankara, Turkey

Department of Pulmonary Diseases

${ }^{4}$ Atatürk Research and Training Hospital, Bilkent, Ankara, Turkey

Department of Biochemistry

${ }^{5}$ Yildirim Beyazit University Medical School, Ankara, Turkey

Department of Biochemistry

\begin{abstract}
Objectives: A water pipe (hookah) is a tobacco smoking tool which is thought to be more harmless than a cigarette, and there are no adequate studies about its hazards to health. Water-pipe smoking is threatening health of the youth in the world today. The objective of this study has been to investigate the carbon monoxide (CO) levels in breath, examine the changes in pulmonary function tests (PFT) and to assess the change of the oxidative stress parameters in blood after smoking a water pipe. Material and Methods: This study is a cross-sectional analytical study that has included 50 volunteers who smoke a water pipe and the control group of 50 volunteers who smoke neither a cigarette nor a water pipe. Carbon monoxide levels were measured in the breath and pulmonary function tests (PFTs) were performed before and after smoking a water pipe. Blood samples were taken from either the volunteer control group or water-pipe smokers group after smoking a water pipe for the purpose of evaluation of the parameters of oxidative stress. Results: Carbon monoxide values were measured to be $8.08 \pm 7.4 \mathrm{ppm}$ and $28.08 \pm 16.5 \mathrm{ppm}$ before and after smoking a water pipe, respectively. This increment was found statistically significant. There were also significant reductions in PFTs after smoking a water pipe. Total oxidative status (TOS), total antioxidant status (TAS) and oxidative stress index (OSI) were found prominently higher after smoking a water pipe for the group of water-pipe smokers than for the control group. Conclusions: This study has shown that water-pipe smoking leads to deterioration in pulmonary function and increases oxidative stress. To the best of our knowledge this study is the only one that has shown the effect of water-pipe smoking on oxidative stress. More studies must be planned to show the side effects of water-pipe habit and protective policies should be planned especially for young people in Europe. Int J Occup Med Environ Health 2017;30(5):731-742
\end{abstract}

Key words:

Oxidative stress, Carbon monoxide, Cigarette smoking, Pulmonary function tests, Antioxidant status, Water-pipe smoking

This study was presented in "Chest World Congress 2014" hold in Madrid, Spain on March 24, 2014 as an oral presentation with 511 reference number. Received: February 1, 2016. Accepted: July 7, 2016.

Corresponding author: M. Er, Atatürk Research and Training Hospital, Department of Pulmonary Diseases, Beytepe Koy yolu 3, Bilkent, 06800 Ankara, Turkey (e-mail: mukreminer@hotmail.com). 


\section{INTRODUCTION}

A water pipe or hookah uses a different kind of tobacco, which is available in most Balkan countries, the Middle East and South Asia [1]. Popularity of smoking a water pipe among European, Canadian, and American young people has shown a dramatic rise over the past decade [2]. The growing popularity of the water pipe use among the U.S. teens and adults is evidenced by media reports and the recent rapid proliferation of the water pipe establishments (bars, cafes, or restaurants) in large cities and near college campuses [3,4].

While a water pipe and hookah are the most common words used among English speakers, other terms include a narghile, goza, ghalyun, shisha, and hubble bubble [5]. Typical water pipes have the following components: a bowl where the tobacco is placed and heated, usually with burning embers or charcoal, a vase or smoke chamber which is partially filled with water, a pipe or stem connecting the bowl to the vase by a tube that carries the smoke down into the water, and a hose with a mouthpiece through which the smoke is drawn from the vase (Figure 1). As the smoker inhales, the tobacco smoke is sucked down from the bowl and then bubbles up through the water into the air of the smoke chamber and then through the hose to the smoker. At the end of a smoking session, the dirty water is thrown away and the water pipe vase is refilled for the next user. Although each smoking session generally lasts about 45-60 min, it may also continue for several hours $[2,6]$.

There is a misconception about smoking a water pipe that it is less harmful than cigarettes, and that's why smoking a water pipe is dramatically increasing especially among young people. While the adverse effects of smoking a cigarette are widely described, there are just a few investigations about a water pipe and its effects. This study was designed to investigate the effects of smoking a water pipe on pulmonary functions and oxidative stress parameters.

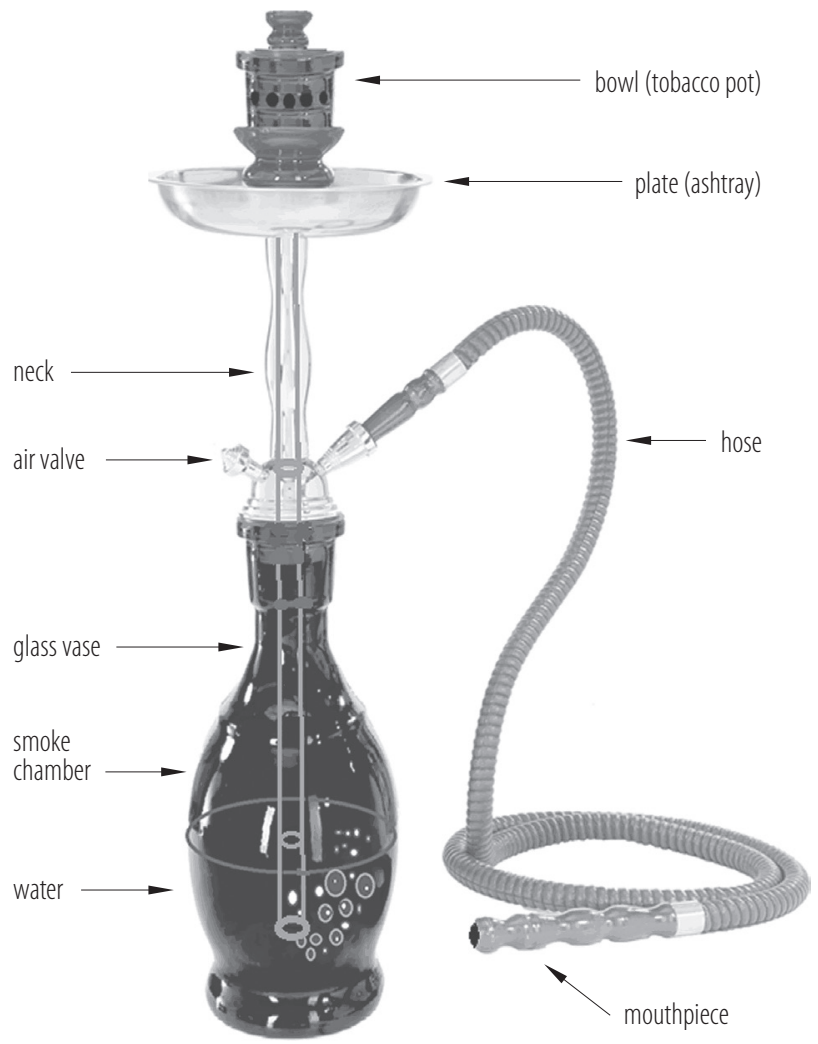

Fig. 1. Elements of a water pipe (hookah)

Oxidative stress is believed to have a key role in the development of chronic diseases. Oxidative stress may develop when the balance between reactive oxygen radicals production and anti-oxidative defense mechanisms is impaired, which may result in cell injury, tissue damage and eventually chronic disease.

\section{MATERIAL AND METHODS}

\section{Study population}

Three water-pipe cafes located in Ankara were visited. Fifty water-pipe smokers aged 18-40 years old, enrolled in the study and created the working group. At the same time, there were also cigarette smokers among those people. The control group consisted of 50 people of the same age and sex, who had never smoked either a cigarette or a water pipe. Demographic characteristics, attitudes and smoking behaviors of the participants as well as their in- 
Table 1. Characteristics of groups taking part in a cross-sectional analytical study investigating changes in pulmonary functions and oxidative stress parameters after smoking a water pipe

\begin{tabular}{|c|c|c|c|}
\hline \multirow{2}{*}{ Variable } & \multicolumn{2}{|c|}{$\begin{array}{l}\text { Study groups } \\
(\mathrm{N}=100)\end{array}$} & \multirow{2}{*}{$\mathrm{p}$} \\
\hline & $\begin{array}{l}\text { water-pipe smokers } \\
\qquad(\mathrm{N}=50)\end{array}$ & $\begin{array}{l}\text { control* }^{*} \\
(\mathrm{~N}=50)\end{array}$ & \\
\hline Age [years] $(\mathrm{M} \pm \mathrm{SD})$ & $26.72 \pm 5.2$ & $27.46 \pm 5.3$ & 0.48 \\
\hline Gender $[\mathrm{n}(\%)]$ & & & 0.83 \\
\hline male & $33(66)$ & $32(64)$ & \\
\hline female & $17(34)$ & $18(36)$ & \\
\hline \multicolumn{4}{|l|}{ Education [n (\%)] } \\
\hline high school & $5(10)$ & $5(10)$ & \\
\hline university & $11(22)$ & $9(18)$ & \\
\hline \multicolumn{4}{|l|}{ Cigarette smoking [n (\%)] } \\
\hline smoker & $24(48)$ & - & \\
\hline quitter & $5(10)$ & $7(14)$ & \\
\hline never smoked & $21(42)$ & $43(86)$ & \\
\hline Alcohol use [n (\%)] & $33(66)$ & $3(6)$ & 0.00 \\
\hline Drug use [n (\%)] & $1(2)$ & - & \\
\hline
\end{tabular}

M - mean; SD - standard deviation.

* Not smoking cigarette nor water pipe.

formation and thoughts about a water pipe were all recorded in this survey.

This study was conducted in accordance with the amended Declaration of Helsinki. The Ethics committee approval was obtained for this cross-sectional analytical study from "Non-drug Clinical Research Ethics Committee of Yildirim Beyazit University School of Medicine, Ankara, Turkey" established under the decision No. 46 dated July 23, 2012, and a written informed consent was obtained from all participants.

\section{Characteristics of the water-pipe group vs. control group}

A water-pipe group and a control group were formed to include 100 people between the ages of 18 to 38.33 years old (mean: $26.72 \pm 5.2$ years old) out of 50 participants of the water-pipe group were males and the remaining 17 were females. In the control group, however, 32 out of 50 were males and the remaining 18 were females (mean age: $27.46 \pm 5.3$ years old). Mean age and gender were not significantly different between the 2 groups ( $p=0.48$ vs. $p=0.83$ ). In the water-pipe group, while 26 of the participants were solely water-pipe smokers, the remaining 24 were smoking cigarettes as well as a water pipe. Thirty-three people from the water-pipe group and 3 people from the control group were alcohol addicts and one person from the water-pipe group was using drugs. The demographic characteristics and habits of participants are summarized in the Table 1. Water-pipe smoking duration, frequency and usage times of the smokers were shown in the Table 2.

\section{Measurement of breath carbon monoxide}

All water-pipe smokers smoked a flavored water pipe for an hour. Carbon monoxide levels were measured in 
Table 2. Smoking behaviors of water-pipe smokers taking part in a cross-sectional analytical study investigating changes in pulmonary functions and oxidative stress parameters after smoking a water pipe

\begin{tabular}{lc}
\hline \multicolumn{1}{c}{ Water-pipe smoking behavior } & $\begin{array}{c}\text { Respondents } \\
(\mathrm{N}=50) \\
{[\mathrm{n}(\%)]}\end{array}$ \\
\hline Using duration & $9(18)$ \\
$<$ 1 year & $20(40)$ \\
1-5 years & $16(32)$ \\
6-10 years & $5(10)$ \\
$>$ 10 years & \\
Usage frequency & $6(12)$ \\
$>$ once a week & $12(24)$ \\
once a week & $2(4)$ \\
$>$ once a month & $16(32)$ \\
once a month & $8(16)$ \\
$>$ once a year & $6(12)$ \\
once a year & \\
Smoking time & $5(10)$ \\
$<1 \mathrm{~h}$ & $25(50)$ \\
1 h & $19(38)$ \\
1-2 h & $1(2)$ \\
\hline
\end{tabular}

the breath both before and 5 min after smoking, using a portable breath carbon monoxide measurement device (Bedfont piCO Smokerlyser, Bedfont Scientific Ltd., Station Road, Harrietsham, Maidstone, Kent, UK). The end-expiratory carbon monoxide (CO) was converted to carbon dioxide by catalytically active electrodes in the device and $\mathrm{CO}$ level in breath was shown at the liquid crystal (LCD) screen as ppm (parts per million).

In the case of the control group (healthy individuals) breath carbon monoxide levels were also measured.

\section{Spirometry}

Pulmonary function tests of all participants were performed both just before and 5 min after smoking a water pipe using the portable spirometry device (MIR Spirolab III, Medi- cal International Research, Rome, Italy). The pulmonary function tests (PFT) were conducted in accordance with the standards of American Thoracic Society. The test was explained to each participant in details and all participants of the study rested during $15 \mathrm{~min}$ before testing and tests were repeated 3 times and best results were chosen for accuracy. Test values were analyzed and computed by the device then either recorded and printed for assessment.

The measured (actual) and percentage of predicted (predicted \%) values of forced expiratory volume in $1 \mathrm{~s}\left(\mathrm{FEV}_{1}\right)$, forced vital capacity (FVC), peak expiratory flow rate (PEF), $\mathrm{FEV}_{1}$ divided by $\mathrm{FVC}\left(\mathrm{FEV}_{1} / \mathrm{FVC}\right)$, forced expiratory flow in $25 \%$ and $75 \%$ of forced vital capacity $\left(\mathrm{FEF}_{25-75 \%}\right)$ parameters were measured for each participant. The predicted values were calculated automatically according to age, sex and height.

Healthy individuals were also subject to pulmonary function tests at any time.

\section{Evaluation of oxidative stress and antioxidant status}

In order to evaluate the parameters of oxidative stress, $3 \mathrm{ml}$ of blood was taken from the control group and the water-pipe smoking group 5 min after water-pipe smoking. Blood samples were centrifuged at $3600 \mathrm{rpm}$ for $6 \mathrm{~min}$ in a biochemistry laboratory and extracted serum samples were stored at $-80^{\circ} \mathrm{C}$ in a refrigerator. Serum samples were used for the purpose of the oxidative stress markers analysis. Total oxidative status (TOS), total antioxidant status (TAS), paraoxonase (PON), saltstimulated paraoxonase (SPON), and arylesterase (ARE) levels were analyzed using colorimetric methods by an auto-analyzer (Hitachi Cobas c501, Roche Diagnostics, Indianapolis, USA).

\section{Oxidative stress index (OSI)}

The oxidative stress index (OSI) is defined as the ratio of the total oxidative status (TOS) to total antioxidant status (TAS) levels and may be measured by means described 
in literature. Measurement of the total oxidant status measurement was performed using the Erel method [7]. The agent was manufactured by Rel Assay (RelAssay, Diagnosticskits, Mega Tip, Gaziantep, Turkey).

In this method, oxidants that are contained in the sample oxidize the ferrous ion-o-dianisidine complex to ferric ion, and glycerol molecules that are abundantly present in the reaction medium enhance the oxidation reaction. The ferric ion produces a complex colored with xylenol orange in an acidic medium. The color intensity is related to the number of oxidant molecules contained in the sample. The assay was calibrated with hydrogen peroxide, and the results were expressed in terms of the micro molar hydrogen peroxide equivalent per liter ( $\mathrm{mmol} \mathrm{H}_{2} \mathrm{O}_{2}$ equivalent/l).

$$
\text { OSI }=\frac{\text { TOS }}{\text { TAS }}
$$

where:

OSI - oxidative stress index,

TOS - total oxidative status in $\mu \mathrm{mol} \mathrm{H}_{2} \mathrm{O}_{2}$ equivalent/l,

TAS - total antioxidant status in mmol Trolox equivalent//×10.

\section{Measurement of paraoxonase activity}

The basal activity of paraoxonase was measured. Paraoxon is a toxic organophosphate that is also known as diethyl-p-nitrophenyl phosphate. The rate of paraoxon hydrolysis was measured by monitoring the absorbance increase at $412 \mathrm{~nm}$ at $37^{\circ} \mathrm{C}$. The amount of p-nitrophenol generated was calculated by means of the molar absorptivity coefficient at $\mathrm{pH}=8$, which was $17.00013 \mathrm{M}^{-1} \times \mathrm{cm}^{-1}$. Paraoxonase activity was expressed in terms of $\mathrm{U} / 1$ serum [8].

\section{Measurement of arylesterase activity}

Phenylacetate was used as a substrate for measuring the arylesterase activity by monitoring its absorbance increase at $270 \mathrm{~nm}$ at $37^{\circ} \mathrm{C}$.
Enzymatic activity was calculated by means of the molar absorptivity coefficient of the produced phenol, which was $1.310 \mathrm{M}^{-1} \times \mathrm{cm}^{-1}$. One unit of arylesterase activity was defined in terms of $1 \mathrm{~mol}$ phenol generated/ min under the above conditions and expressed in terms of $\mathrm{kU} / 1$ serum [8].

\section{Statistical analysis}

The findings of the study were assessed for the purpose of the statistical analysis using SPSS 20.0 (Statistical Package for Social Science Statistics for Windows, Version 20.0, IBM Corp., New York, USA). Descriptive statistics were computed for each of the variables analyzed. Results are presented as the mean $(\mathrm{M}) \pm$ standard deviation (SD). In order to compare the different groups stratified by age and sex, the independent samples t-test and $\mathrm{Chi}^{2}$ tests were used. One-way analysis of variance (ANOVA) and Kruskal-Wallis tests were used for the purpose of the comparison of the independent samples from more than 2 groups. P value $<0.05$ was considered significant.

\section{RESULTS}

\section{Comparative analyses of $\mathrm{CO}$ levels,} pulmonary function tests and oxidative stress

\section{parameters between the $\mathbf{2}$ groups}

Before smoking a water pipe, levels of $\mathrm{CO}$ - in a cigarette plus water-pipe smokers: $12.46 \mathrm{ppm}$, exclusively water-pipe smokers: $4.04 \mathrm{ppm}$, and the control group: $1.54 \mathrm{ppm}$ - were all significantly different from one another. However, $\mathrm{CO}$ levels were found significantly higher in a cigarette plus water-pipe smokers (33.42 ppm) than exclusively water-pipe smokers (23.15 ppm) after smoking a water pipe but the mean level of the control group was as low as 1.54 ppm in terms of permissible limits. Eventually, the average CO level increased from $8.08 \mathrm{ppm}$ to $28.08 \mathrm{ppm}$ after smoking a water pipe, which are all shown in the Figure 2. 


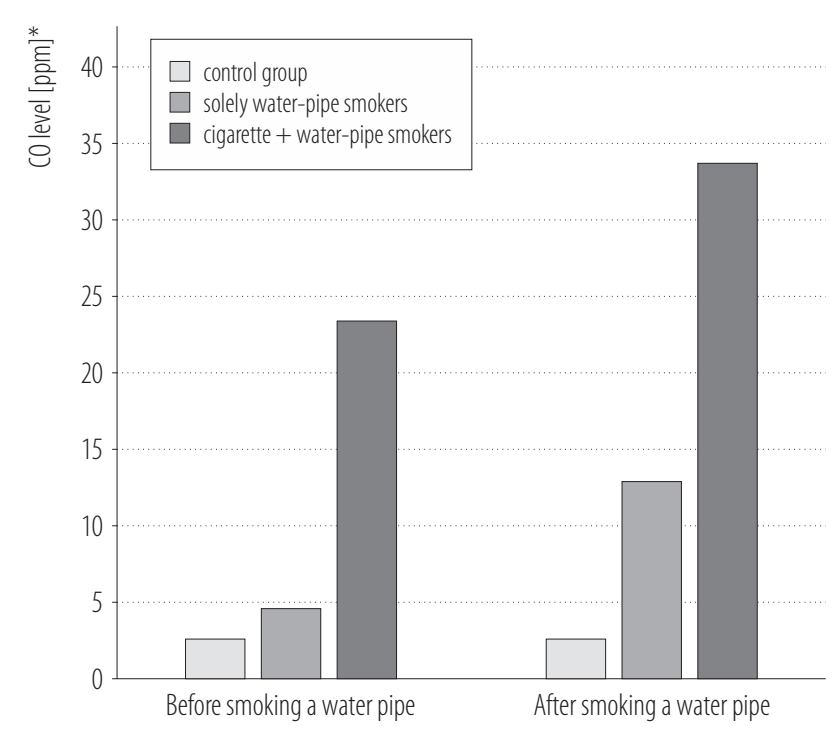

* 5 ppm was taken as cut-off value for CO level.

Fig. 2. Comparisons of carbon monoxide (CO) levels in groups taking part in a cross-sectional analytical study investigating changes in pulmonary functions and oxidative stress parameters after smoking a water pipe

Before smoking a water pipe, $\mathrm{FVC}$ and $\mathrm{FEV}_{1}$ values of PFT were significantly lower in a cigarette plus wa- ter-pipe smokers as compared to exclusively water-pipe smokers and the control group. Forced expiratory volume in $1 \mathrm{~s}$ to forced vital capacity ratio parameter was also significantly lower in a cigarette plus water-pipe smokers as compared to the control group (Table 3). After smoking a water pipe, $\mathrm{FVC}$ and $\mathrm{FEF}_{25-75 \%}$ values were significantly lower in a cigarette plus water-pipe smokers as compared to exclusively water-pipe smokers and the control group. Meanwhile, $\mathrm{FEV}_{1}$ and $\mathrm{FEV}_{1} / \mathrm{FVC}$ parameters were also significantly lower in a cigarette plus water-pipe smokers as compared to the control group (Table 4). All water-pipe smokers' PFT parameters were evaluated after smoking a water pipe and $\mathrm{FVC}, \mathrm{FEV}_{1}, \mathrm{PEF}$ and $\mathrm{FEF}_{25-75 \%}$ parameters were found to have significantly decreased as compared to their pre-smoking values (Table 5).

Parameters of oxidative stress in the blood after smoking a water pipe, the average values of TOS and OSI were compared with the control group values and results indicated a significant increase $(\mathrm{p}<0.00)$. Paraoxonase and SPON are anti-oxidative parameters; after smoking

Table 3. Comparison of pulmonary function tests (PFT) parameters before smoking a water pipe in groups taking part in a cross-sectional analytical study investigating changes in pulmonary functions and oxidative stress parameters after smoking a water pipe

\begin{tabular}{|c|c|c|c|}
\hline \multirow{3}{*}{ PFT parameter } & \multicolumn{3}{|c|}{$\begin{array}{l}\text { Study groups } \\
(\mathrm{N}=100)\end{array}$} \\
\hline & \multicolumn{2}{|c|}{ before smoking a water pipe } & \multirow[b]{2}{*}{$\begin{array}{l}\text { control } \\
(\mathrm{N}=50)\end{array}$} \\
\hline & $\begin{array}{c}\text { only water-pipe } \\
\text { smokers } \\
(\mathrm{N}=26)\end{array}$ & $\begin{array}{c}\text { cigarette plus } \\
\text { water-pipe smokers } \\
(\mathrm{N}=24)\end{array}$ & \\
\hline Forced vital capacity $(\mathrm{FVC} \%)[1](\mathrm{M} \pm \mathrm{SD})$ & $99.77 \pm 9.6^{*}$ & $93.33 \pm 4.0 *$ & $100.62 \pm 9.1^{*}$ \\
\hline Forced expiratory volume in $1 \mathrm{~s}\left(\mathrm{FEV}_{1} \%\right)[\mathrm{l}](\mathrm{M} \pm \mathrm{SD})$ & $95.88 \pm 10.1^{*}$ & $89.50 \pm 4.6^{*}$ & $96.74 \pm 9.8^{*}$ \\
\hline $\begin{array}{l}\text { Forced expiratory volume in } 1 \mathrm{~s} \text { to forced vital capacity ratio } \\
\left(\mathrm{FEV}_{\mathrm{l}} / \mathrm{FVC}\right)[\mathrm{l}](\mathrm{M} \pm \mathrm{SD})\end{array}$ & $85.65 \pm 4.3$ & $84.26 \pm 5.1^{* *}$ & $87.70 \pm 5.5^{* *}$ \\
\hline Peak expiratory flow rate $(\mathrm{PEF} \%)[1](\mathrm{M} \pm \mathrm{SD})$ & $95.23 \pm 20.6$ & $94.79 \pm 14.6$ & $90.20 \pm 13.5$ \\
\hline $\begin{array}{l}\text { Forced expiratory flow in } 25 \% \text { and } 75 \% \text { of forced vital } \\
\text { capacity }\left(\mathrm{FEF}_{2577^{\circ}}\right)[1](\mathrm{M} \pm \mathrm{SD})\end{array}$ & $92.15 \pm 21.3$ & $87.50 \pm 13.1$ & $93.96 \pm 21.0$ \\
\hline
\end{tabular}

M - mean; SD - standard deviation.

* There were statistically meaningful differences between the control group - a cigarette plus water-pipe smokers group and only water-pipe smokers group - a cigarette plus water-pipe smokers group in $\mathrm{FVC}_{\%}$ and $\mathrm{FEV}_{1} \%(\mathrm{p}<0.05)$.

** There was a statistically meaningful difference between the control group - a cigarette plus water-pipe smokers group in $\mathrm{FEV} / \mathrm{FVC}(\mathrm{p}<0.05)$. 
Table 4. Comparison of pulmonary function tests (PFT) parameters after smoking a water pipe in groups taking part in a cross-sectional analytical study investigating changes in pulmonary functions and oxidative stress parameters after smoking a water pipe

\begin{tabular}{|c|c|c|c|}
\hline \multirow{3}{*}{ PFT parameter } & \multicolumn{3}{|c|}{$\begin{array}{l}\text { Study groups } \\
(\mathrm{N}=100)\end{array}$} \\
\hline & \multicolumn{2}{|c|}{ after smoking a water pipe } & \multirow{2}{*}{$\begin{array}{l}\text { control } \\
(\mathrm{N}=50)\end{array}$} \\
\hline & $\begin{array}{l}\text { only water-pipe smokers } \\
\qquad(\mathrm{N}=26)\end{array}$ & $\begin{array}{l}\text { cigarette plus water-pipe smokers } \\
\qquad(\mathrm{N}=24)\end{array}$ & \\
\hline $\mathrm{FVC} \%[\mathrm{l}](\mathrm{M} \pm \mathrm{SD})$ & $96.62 \pm 9.6^{*}$ & $90.25 \pm 4.8^{*}$ & $100.62 \pm 9.1^{*}$ \\
\hline $\mathrm{FEV}_{1} \%[\mathrm{l}](\mathrm{M} \pm \mathrm{SD})$ & $92.19 \pm 9.4$ & $86.79 \pm 5.0^{* *}$ & $96.74 \pm 9.8^{* *}$ \\
\hline $\mathrm{FEV}_{1} / \mathrm{FVC}[1](\mathrm{M} \pm \mathrm{SD})$ & $85.64 \pm 7.5$ & $84.05 \pm 5.1^{* *}$ & $87.70 \pm 5.5^{* *}$ \\
\hline $\mathrm{PEF} \%[1](\mathrm{M} \pm \mathrm{SD})$ & $90.88 \pm 25.5$ & $90.25 \pm 15.2$ & $90.20 \pm 13.5$ \\
\hline $\mathrm{FEF}_{25-75 \%}[\mathrm{l}](\mathrm{M} \pm \mathrm{SD})$ & $82.46 \pm 21.9^{*}$ & $85.00 \pm 15.0^{*}$ & $93.96 \pm 21.0^{*}$ \\
\hline
\end{tabular}

Abbreviations as in Table 3.

* There were statistically differences between only water-pipe smokers group - a cigarette plus water-pipe smokers group, control group - only waterpipe smokers group and control group - cigarette plus water-pipe smokers group in $\mathrm{FVC}$ and $\mathrm{FEF}_{25-75 \%}(\mathrm{p}<0.05)$.

** There were statistically differences between control group - cigarette plus water-pipe smokers group in $\mathrm{FEV}_{1}$ and $\mathrm{FEV}_{1} / \mathrm{FVC}(\mathrm{p}<0.05)$.

Table 5. Comparisons of pulmonary function tests (PFT) parameters in water-pipe smokers group taking part in a cross-sectional analytical study investigating changes in pulmonary functions and oxidative stress parameters after smoking a water pipe

\begin{tabular}{|c|c|c|c|}
\hline \multirow[t]{2}{*}{ PFT parameter } & \multicolumn{2}{|c|}{$\begin{array}{l}\text { Respondents } \\
(\mathrm{N}=50)\end{array}$} & \multirow[t]{2}{*}{$\mathrm{p}$} \\
\hline & before smoking a water pipe & after smoking a water pipe & \\
\hline $\mathrm{FVC} \%[\mathrm{l}](\mathrm{M} \pm \mathrm{SD})$ & $96.68 \pm 8.1$ & $93.56 \pm 8.3$ & $0.00^{*}$ \\
\hline $\mathrm{FEV}_{1} \%[\mathrm{l}](\mathrm{M} \pm \mathrm{SD})$ & $92.82 \pm 8.5$ & $89.60 \pm 8.0$ & $0.00^{*}$ \\
\hline $\mathrm{FEV}_{1} / \mathrm{FVC}[\mathrm{l}](\mathrm{M} \pm \mathrm{SD})$ & $84.98 \pm 4.7$ & $84.88 \pm 6.5$ & 0.12 \\
\hline PEF\% [l] $(\mathrm{M} \pm \mathrm{SD})$ & $95.02 \pm 17.8$ & $90.58 \pm 21.0$ & $0.01^{*}$ \\
\hline $\mathrm{FEF}_{25-75 \%}[1](\mathrm{M} \pm \mathrm{SD})$ & $89.92 \pm 17.8$ & $83.66 \pm 18.8$ & $0.00^{*}$ \\
\hline
\end{tabular}

Abbreviations as in Table 3.

* There were statistically meaningful differences between before and after smoking a water pipe in $\mathrm{FVC}, \mathrm{FEV}_{1}, \mathrm{PEF}$ and $\mathrm{FEF}_{25-75 \%}(\mathrm{p}<0.05)$.

a water pipe, SPON was found to be significantly lower than the control group. Arylesterase is another antioxidative parameter and its mean value was higher for the water-pipe smoking group than the control group, but the difference was not statistically significant (Table 6).

\section{DISCUSSION}

The recent global expansion of the water pipe use by young adults to smoke tobacco poses a new challenge for the tobacco control community [3,9]. It is currently estimated that 100 million people use a water pipe to smoke tobacco every day worldwide [10]. Teens and young adults are susceptible to the water pipe use because of their tendency to explore new things. If they start smoking tobacco at an early age they are more likely to become addicted to nicotine than those who start later. On the other hand, those using water pipes are in the danger of transition to cigarettes as their addiction becomes stronger [11]. In this study, most of the participants were young adult water-pipe smokers, a half of whom were smoking cigarettes at the same time. 
Table 6. Comparisons of oxidant and antioxidant parameters between water-pipe smokers group and control group taking part in a cross-sectional analytical study investigating changes in pulmonary functions and oxidative stress parameters after smoking a water pipe

\begin{tabular}{|c|c|c|c|}
\hline \multirow[b]{2}{*}{ Oxidant and antioxidant parameter } & \multicolumn{2}{|c|}{$\begin{array}{l}\text { Study groups } \\
(\mathrm{N}=100)\end{array}$} & \multirow[b]{2}{*}{$\mathrm{p}$} \\
\hline & $\begin{array}{c}\text { water-pipe smokers } \\
\text { (after smoking a water pipe) } \\
(\mathrm{N}=50)\end{array}$ & $\begin{array}{c}\text { control } \\
(\mathrm{N}=50)\end{array}$ & \\
\hline Total antioxidant status (TAS) [mmol Trolox equivalent/l] $(\mathrm{M} \pm \mathrm{SD})$ & $2.31 \pm 0.24$ & $2.00 \pm 0.20$ & $0.00^{*}$ \\
\hline Total oxidative status (TOS) $\left[\mu \mathrm{mol} \mathrm{H}_{2} \mathrm{O}_{2}\right.$ equivalent/l] $(\mathrm{M} \pm \mathrm{SD})$ & $9.81 \pm 4.79$ & $3.21 \pm 2.46$ & $0.00^{*}$ \\
\hline Oxidative stress index $(\mathrm{OSI})(\mathrm{M} \pm \mathrm{SD})$ & $0.42 \pm 0.18$ & $0.15 \pm 0.11$ & $0.00^{*}$ \\
\hline Paroxonase (PON) [U/l] $(\mathrm{M} \pm \mathrm{SD})$ & $164.25 \pm 114.49$ & $202.21 \pm 112.13$ & 0.09 \\
\hline Salt-stimulated paroxonase (SPON) [U/l] $(\mathrm{M} \pm \mathrm{SD})$ & $414.32 \pm 304.02$ & $551.18 \pm 335.66$ & $0.01^{*}$ \\
\hline Arylesteraz (ARE) [U/l] $(\mathrm{M} \pm \mathrm{SD})$ & $241.15 \pm 50.32$ & $233.95 \pm 52.53$ & 0.48 \\
\hline
\end{tabular}

* There were statistically meaningful differences between the water-pipe smokers group (after smoking a water pipe) and control group in oxidant and antioxidant parameters $(\mathrm{p}<0.05)$.

During the past century most water pipe smokers were elderly and retired men who congregated in bazaar cafes in poor neighborhoods [6,12]. Since 1990s, using a water pipe has rapidly expanded and become popular among young adults, women and students [13-15]. In this study, $34 \%$ and $32 \%$ of the participants were women and students respectively, which is consistent with the literature. In this study, the habit of drinking alcohol was found to be more common among water-pipe smokers than nonsmokers (control group). And one of the participants in the water-pipe group was on drugs. It has been shown in several studies that using alcohol increases the risk of smoking a cigarette and a water pipe $[4,16,17]$.

In previous studies it was shown that smoking a water pipe increases the levels of CO in blood [18-20] and in breath $[5,21,22]$. In our study, on the other hand, we showed that the mean level of CO in the breath of the water-pipe smokers before smoking was significantly higher as compared to the control group. This result may be explained by carbon monoxide bounds hemoglobin irreversible therefore it has long wash-out time from the body. Comparing to the control group, levels of $\mathrm{CO}$ were found to increase about 30 times for water-pipe smokers after smoking. Increased CO levels were significantly higher in a cigarette plus water-pipe smokers than in the exclusively water-pipe smokers. The highest $\mathrm{CO}$ value was measured to be 99 ppm after smoking a water pipe. Burning coal may have an impact on these escalated levels of CO. Indeed, many harmful gases are emitted to the environment by the burning of coal. Only one of them is $\mathrm{CO}$ [22].

Zahran et al. [20] have demonstrated a high percentage rate of carboxyhemoglobin $(\mathrm{COHb})$ in the group of water-pipe smokers as compared to the cigarette smokers group or to the control group who did not smoke. In addition symptoms indicating $\mathrm{CO}$ poisoning, such as blurred vision, rapid pulse, and dizziness were more frequent for water-pipe smokers than cigarette smokers [20]. Support for the above findings was obtained in the research done by Singh et al. in India [23]. Levels of $\mathrm{COHb}$ and blood cholesterol of smokers of various tobacco types such as cigarettes and water pipes were compared. The highest levels of $\mathrm{COHb}$ were found among those who had smoked a water pipe for more than 10 years [23]. Even a single water pipe run resulted in increased end-expiratory CO [5]. In a study of Hakim 
et al. [24] it has been shown that levels of CO increase from 1.47 ppm to 9.47 ppm after 30 min of water-pipe smoking. These results of previous research support this study.

The effects of smoking cigarettes on PFT parameters have been shown in numerous studies [25-28] whereas very few studies are available about PFT parameters in water-pipe smoking $[29,30]$. In this study, we found that different parameters of PFT were significantly lower for the water pipe plus cigarette smokers than the exclusively waterpipe smokers and the control group, both before and after smoking. Finally, the comparison between pre-smoking values and post-smoking ones shows that all PFT parameters except for $\mathrm{FEV}_{1} / \mathrm{FVC}$ decrease in the case of waterpipe smokers. In the study of Kiter et al. [29], the effect of water-pipe smoking on PFT parameters was investigated. There were 3 groups of smokers and the non-smokers control group. The first group included water-pipe smokers, the second one included water-pipe smokers who had quit cigarette smoking and the last one included cigarette smokers. PFT parameters were eventually found to decrease in all 3 groups compared to the control group. In the same study, the results of PFT parameters of cigarette smokers were lower than the water-pipe smokers. The insufficient number of participants and including only men were the limitations of this study [29].

Zahran et al. [20] explained the significant decrease in $\mathrm{FEV}_{1} / \mathrm{FVC}$ and maximum mid-expiratory flow (MMEF) of cigarette and water-pipe smokers as a result of partial obstruction of all small airways. Although the mean FVC has been found to be slightly higher for the water-pipe smokers than for the cigarette smokers, the study sample has not been large enough to make precise comments [20]. Layoun et al. observed the decrease in PFT parameters in both cigarette and water-pipe smokers but there were more declines on cardiovascular indices for water-pipe smokers than cigarette smokers [30].

Free radicals and oxidants such as superoxide radical anions are produced in metabolic and physiological process- es while burning water-pipe tobacco [31]. The oxidative effects of free radicals are controlled by exogenous antioxidants, such as vitamins $\mathrm{E}$ and $\mathrm{C}$, and also by endogenous antioxidants, such as the scavenger enzymes superoxide dismutase, glutathione peroxidase and catalase, as well as albumin, bilirubin and uric acid. Under some conditions, increases in oxidants and decreases in antioxidants cannot be prevented, and the oxidant-antioxidant balance shifts toward the oxidative stress [32]. Blood serum contains many antioxidant molecules that prevent and/or inhibit harmful free radical reactions [33].

Exposure to oxidative stress has been implicated in the pathogenesis of over 100 disorders including atherosclerosis [34]. Plasma concentrations of antioxidants may be measured separately in the laboratory [35]. We used a method, which had already been developed by Erel as a measurement test in order to evaluate the total antioxidant stress of plasma [36]. There are a few published studies related to the oxidative stress of smoking cigarette [37-39]. It is thought that smoking a water pipe has the similar effects like a cigarette, but there are no investigations about it in the literature yet. In this study, levels of TOS and OSI after smoking a water pipe were found to increase in water-pipe smokers than the control group as expected. It was observed that levels of TAS increased after smoking a water pipe too whereas in previous studies levels of TAS were found to be lower for cigarette smokers [37-39].

To understand the underlying reason, the liquid sample was taken from the bottle of a water pipe before and after smoking and the results were compared. Similarly the levels of TOS and TAS of the liquid in the water pipe bottle were found to increase after smoking. This unexpected result may be explained by using various fruit flavors. Due to the lack of studies in this field, our findings are not enough to make precise comments. PON and SPON are also the antioxidant parameters that were measured to be significantly lower than the control group after smoking a water 
pipe. Arylesterase is another antioxidant parameter and its mean value is higher for the water-pipe smoking group than the control group, but the difference has not been statistically significant. This unexpected decrease in ARE may be explained by the same reason causing the decrease in TAS. Therefore, more detailed investigations are needed to assess the effects of smoking a water pipe.

\section{CONCLUSIONS}

The results of this study have shown that smoking a water pipe leads to deterioration in oxidative stress and respiratory functions and we may use measurement of the breath carbon monoxide level for predicting the oxidative stress level and deteriorations of pulmonary functions. There are no studies showing the effect of smoking a water pipe on oxidative stress to date. There is a misconception according to which a water pipe is believed to be less harmful than cigarettes, and that's why, smoking a water pipe is increasing dramatically especially among young generations. Societies must be informed about the painful truth behind a water pipe in order to prevent the youth from tobacco related diseases that they may face in future. More studies need to be conducted to investigate other unknown effects of a water pipe on the oxidant/antioxidant system in human body. We may use breath carbon monoxide measurement which is an inexpensive and very easy method to predict oxidative stress level therefore we prevent youth from smoking related diseases such as chronic obstructive pulmonary disease (COPD) and lung cancer.

\section{REFERENCES}

1. Moon KA, Magid H, Torrey C, Rule AM, Ferguson J, Susan J, et al. Secondhand smoke in waterpipe tobacco venues in Istanbul, Moscow, and Cairo. Environ Res. 2015;142:568-74, https://doi.org/10.1016/j.envres.2015.08.012.

2. Maziak W. The global epidemic of hookah smoking. Addict Behav. 2011;36(1-2):1-5, https://doi.org/10.1016/j.addbeh.2010.08.030.
3. Maziak W, Ward KD, Afifi Soweid RA, Eisenberg T. Tobacco smoking using a hookah: A re-emerging strain in a global epidemic. Tob Control. 2004;13(4):327-33, https:// doi.org/10.1136/tc.2004.008169.

4. Dugas E, Tremblay M, Low NC, Cournoyer D, O'Loughlin J. Water-pipe smoking among North American youths. Pediatrics. 2010;125(6):1184-9, https://doi.org/10.1542/peds.2009-2335.

5. Shafagoj YA, Mohammed FI. Levels of maximum endexpiratory carbon monoxide and certain cardiovascular parameters following hubble-bubble smoking. Saudi Med J. 2002;23(8):953-8.

6. Knishkowy B, Amitai Y. Water-pipe (narghile) smoking: An emerging health risk behavior. Pediatrics. 2005;116(1): e113-9, https://doi.org/10.1542/peds.2004-2173.

7. Erel O. A new automated colorimetric method for measuring total oxidant status. Clin Biochem. 2005;38(12):1103-11, https://doi.org/10.1016/j.clinbiochem.2005.08.008.

8. Haagen L, Brock A. A new automated method for phenotyping arylesterase (E.C.3.1.1.2.) based upon inhibition of enzymatic hydrolysis of 4-nitrophenyl acetate by phenyl acetate. Eur J Clin Chem Clin Biochem. 1992;30:391-5.

9. Martinasek MP, Gibson-Young LM, Davis JN, McDermott RJ. Waterpipe tobacco smoking impact on public health: Implications for policy. Risk Manag Healthc Policy. 2015;8:121-9, https://doi.org/10.2147/RMHP.S68267.

10. Wolfram RM, Chehne F, Oguogho A, Sinzinger H. Narghile (water pipe) smoking influences platelet function and (iso-) eicosanoids. Life Sci. 2003;74(1):47-53, https://doi.org/10. 1016/j.lfs.2003.06.020.

11. Rice VH, Templin T, Kulwicki A. Arab-American adolescent tobacco use: Four pilot studies. Prev Med. 2003;37(5): 492-8, https://doi.org/10.1016/S0091-7435(03)00175-0.

12. Kandela P. Nargile smoking keeps Arabs in Wonderland. Lancet. 2000;356(9236):1175, https://doi.org/10.1016/S01406736(05)72871-3.

13. Al-Belasy FA. The relationship of "shisha" (water pipe) smoking to postextraction dry socket. J Oral Maxillofac Surg. 2004;62:10-4, https://doi.org/10.1016/j.joms.2002.11.001. 
14. Maziak W, Fouad FM, Asfar T, Hammal F, Bachir EM, Rastam S, et al. Prevalence and characteristics of narghile smoking among university students in Syria. Int J Tuberc Lung Dis. 2004;8(7):882-9.

15. Baheiraei A, Shahbazi Sighaldeh S, Ebadi A, Kelishadi R, Majdzadeh SR. Psycho-social needs impact on hookah smoking initiation among women: A qualitative study from Iran. Int J Prev Med. 2015;6:79, https://doi.org/10.4103/20 08-7802.163374.

16. Sidani JE, Shensa A, Barnett TE, Cook RL, Primack BA. Knowledge, attitudes, and normative beliefs as predictors of hookah smoking initiation: A longitudinal study of university students. Nicotine Tob Res. 2014;16(6):647-54, https:// doi.org/10.1093/ntr/ntt201.

17. Rezk-Hanna M, Macabasco-O'Connell A, Woo M. Hookah smoking among young adults in southern California. Nurs Res. 2014;63(4):300-6, https://doi.org/10.1097/NNR. 0000000000000038.

18. Shihadeh A, Saleh R. Polycyclic aromatic hydrocarbons, carbon monoxide, "tar", and nicotine in the mainstream smoke aerosol of the narghile water pipe. Food Chem Toxicol. 2005;43(5):655-61, https://doi.org/10.1016/j.fct.2004.12.013.

19. Asfar T, Ward KD, Eissenberg T, Maziak W. Comparison of patterns of use, beliefs, and attitudes related to hookah between beginning and established smokers. BMC Public Health. 2005;5:19, https://doi.org/10.1186/1471-2458-5-19.

20. Zahran F, Yousef AA, Baig MH. A study of carboxyhaemoglobin levels of cigarette and sheesha smokers in Saudi Arabia. Am J Public Health. 1982;72(7):722-4, https://doi. org/10.2105/AJPH.72.7.722.

21. Clarke SF, Stephens C, Farhan M, Ward P, Keshishian C, Murray $\mathrm{V}$, et al. Multiple patients with carbon monoxide toxicity from water-pipe smoking. Prehosp Disaster Med. 2012;27(6):612-4, https://doi.org/10.1017/S1049023 X12001227.

22. Middleton ET, Morice AH. Breath carbon monoxide as an indication of smoking habit. Chest. 2000;117(3):758-63, https://doi.org/10.1378/chest.117.3.758.
23. Singh N, Singh J, Singh A, Kaur K, Singh G. Carboxyhaemoglobin and serum cholesterol levels in smokers. J Assoc Physicians India. 1989;37(10):649-51.

24. Hakim F, Hellou E, Goldbart A, Katz R, Bentur Y, Bentur L. The acute effects of water-pipe smoking on the cardiorespiratory system. Chest. 2011;139(4):775-81, https:// doi.org/10.1378/chest.10-1833.

25. Sherrill DL, Lebowitz MD, Knudson RJ, Burrows B. Longitudinal methods for describing the relationship between pulmonary function, respiratory symptoms and smoking in elderly subjects: The Tucson Study. Eur Respir J. 1993;6(3):342-8.

26. Flouris AD, Chorti MS, Poulianiti KP, Jamurtas AZ, Kostikas K, Tzatzarakis MN, et al. Acute impact of active and passive electronic cigarette smoking on serum cotinine and lung function. Inhal Toxicol. 2013;25(2):91-101, https://doi. org/10.3109/08958378.2012.758197.

27. Tantisuwat A, Thaveeratitham P. Effects of smoking on chest expansion, lung function, and respiratory muscle strength of youths. J Phys Ther Sci. 2014;26(2):167-70, https://doi.org/10.1589/jpts.26.167.

28. Shin JY, Shim JY, Lee DC, Lee HR. Smokers with adequate vitamin $\mathrm{C}$ intake show a preferable pulmonary function test. J Am Coll Nutr. 2015;34(5):385-90, https://doi.org/10.1080/ 07315724.2014.926152.

29. Kiter G, Ucan ES, Ceylan E, Kilinç O. Water-pipe smoking and pulmonary functions. Respir Med. 2000;94(9):891-4, https://doi.org/10.1053/rmed.2000.0859.

30. Layoun N, Saleh N, Barbour B, Awada S, Rachidi S, AlHajje A, et al. Waterpipe effects on pulmonary function and cardiovascular indices: A comparison to cigarette smoking in real life situation. Inhal Toxicol. 2014;26(10):620-7, https://doi.org/10.3109/08958378.2014.945106.

31. Urkin J, Ochaion R, Peleg A. Hubble bubble equals trouble: The hazards of water pipe smoking. Scientific World Journal. 2006;6:1990-7, https://doi.org/10.1100/tsw.2006.332.

32. McMurray J, McLay J, Chopra M, Bridges A, Belch JJ. Evidence for enhanced free radical activity in chronic 
congestive heart failure secondary to coronary artery disease. Am J Cardiol. 1990;65(18):1261-2, https://doi.org/ 10.1016/0002-9149(90)90985-A.

33. Young IS, Woodside JV. Antioxidants in health and disease. J Clin Pathol. 2001;54(3):176-86, https://doi.org/10.1136/ jcp.54.3.176.

34. Karabacak M, Dogan A, Tayyar S, Bas HA. Oxidative stress status increase in patients with nonischemic heart failure. Med Princ Pract. 2014;23(6):532-7, https://doi.org/ 10.1159/000365512.

35. Gutteridge JM. Lipid peroxidation and antioxidants as biomarkers of tissue damage. Clin Chem. 1995;41(12 Pt 2): 1819-28.

36. Erel O. A novel automated direct measurement method for total antioxidant capacity using a new generation, more stable ABTS radical cation. Clin Biochem. 2004;37(4): 277-85, https://doi.org/10.1016/j.clinbiochem.2003.11.015.

37. Kösecik M, Erel Ö, Sevinç E, Selek S. Increased oxidative stress in children exposed to passive smoking. Int J Cardiol. 2005;100:61-4, https://doi.org/10.1016/j.ijcard.2004.05.069.

38. Senti M, Tomás M, Anglada R, Elosua R, Marrugat J, Covas, et al. Interrelationship of smoking, paraoxonase activity, and leisure time physical activity: A population-based study. Eur J Intern Med. 2003;14(3):178-84, https://doi. org/10.1016/S0953-6205(03)00041-4.

39. Szulińska M, Piorunek T, Suliburska J, Pupek-Musialik D, Kupsz J, Drzymala-Czyż S, et al. Evaluation of insulin resistance, tumor necrosis factor alpha, and total antioxidant status in obese patients smoking cigarettes. Eur Rev Med Pharmacol Sci. 2013;17(14):1916-22.

This work is available in Open Access model and licensed under a Creative Commons Attribution-NonCommercial 3.0 Poland License - http://creativecommons.org/ licenses/by-nc/3.0/pl/deed.en. 